\title{
Development of guided inquiry based modules to improve learning outcomes and metacognition skills of student
}

\author{
Intan Pratiwi ${ }^{1{ }^{1}{ }^{*}, \text { Ismanisa }}{ }^{1}$, Asep Wahyu Nugraha ${ }^{2}$ \\ 'Masters in Chemical Education, Postgraduate, Universitas Negeri Medan, Medan 2022l, Indonesia \\ ${ }^{2}$ Department of Chemistry, Universitas Negeri Medan, Medan 20221, Indonesia \\ ${ }^{*}$ Corresponding author: (IP); intanpratiwi7ll@gmail.com
}

Received: 21 June $2019 \quad$ Accepted: 28 August 2019

\begin{abstract}
:
This study aims to find out the guided inquiry-based acid-base module that have been developed meets the criteria of the National Education Standards Agency (BSNP); learning outcomes increase after being taught using guided inquiry based modules; there is a relationship between student learning outcomes with student metacognition skills. The population was all students of class $\mathrm{XI}$ Senior High School Education Foundation Mulia Medan Academic. Class XI Science was chosen as the sample determined by simple random sampling. The research method used is the development research using the ADDIE model (Analysis, Design, Development, Implementation, and Evaluation). The research instrument was a learning outcome test, a metacognitive questionnaire taken from the Metacognitive Awareness Inventory (MAl) instrument, and a validation sheets. Data analysis was conducted using descriptive analysis, feasibility analysis, the results of the metacognitive questionnaire, and the results of learning tests. The hypothesis test using the t-test and assisted with the SPSS 19.0. The results of the study showed that the modules were developed according to the criteria of the National Education Standards Agency (BSNP)obtained: content = 3.85; language $=3.89$; presentation $=3.83$; graphic $=3.87$ with valid criteria; $t_{\text {count }}$ is greater than $t_{\text {table }}$ $(8.321>1.708)$ shows that student chemistry learning outcomes increase after being taught using guided inquiry-based modules; the results of the correlation obtained $r_{\text {count }}>r_{\text {table }}(0.472>0.388)$ showed that there is a relationship between metacognition skills and chemistry learning outcomes of students.
\end{abstract}

Keywords:

Development research; learning outcomes;guided inquiry; metacognition skills; module

\section{Introduction}

Chemistry is defined as the study of composition, structure, properties, and changes in matter, and the energy that accompanies this change. In chemistry learning,problems in chemistry are classified as complex subjects so there is an impression that chemistry is a difficult science (Dewi, 2015).

Based on the facts from the results of the study of Novratilova et al. (2015), chemistry is considered a science that is quite difficult to understand, and not interesting to learn. Research supported by Marsita et al. (2010), which states that the cause of students experiencing difficulties in learning chemistry is the lack of interest and attention of students during the learning process in chemistry. According to Ristiyani et al. (2016), the learning process in schools looks less attractive, so students feel satisfied and less interested in chemistry lessons. Students who have difficulty learning to understand the concepts that exist in chemistry because of the inability to connect the macroscopic and microscopic world. Various studies have been conducted to examine 
this. Weerawardhana et al. (2006) have proposed four main questions that make it difficult for most students to understand chemical concepts, namely chemistry learning, chemistry learning methods, student learning methods, and learning media. One media of learning is a module.

Modules are a way of organizing subject matter that takes into account the function of education. The strategy of organizing the subject matter contains squencing which refers to the making of the sequence of presentation of subject matter, and synthesizing which refers to efforts to show the learners the relationship between facts, concepts, procedures and principles contained in the chemistry learning (Santyasa, 2011). A teacher must be smart to create a conducive learning context in the school environment. Therefore, there is a need for new innovations to develop a good teaching subjects or good media in order to attract students to learn and like the lessons that the teacher will convey (Tiring et al. 2015).

The indicator of the success of a teacher in the learning process is by changing the attitudes or knowledge of students who have experienced the learning process. Learning methods that can activate students in the learning process using the inquiry method. Wallace and Metz (in Bilgin, 2009) said that the important thing in the application of inquiry learning is students who act as problem solving of the problems given and teachers as their mentors.

Inquiry learning methods involve students actively in the learning process. The use of inquiry learning method is expected to be able to know the level of students' metacognition skills. The chemistry learning process in the 2013 curriculum, teachers are expected to facilitate and encourage students to think critically, logically, and systematically, and to have High Order Thinking Skill (HOTS). High Order Thinking Skills that need to be trained by teachers in managing chemical learning in the classroom, one of which is metacognition skills.

The development of students' metacognitive skills is very dependent on the learning patterns used by the teacher. According to Slavin (in Danial, 2010), metacognition is knowledge about selflearning or knowledge of learning. Metacognition skills are methods for learning, studying or solving questions. The application of metacognition skills is the ability to think about subjects matter that has been studied, then students independently deduce whether students have understood the material or not.

The development of inquiry-based chemical modules is expected to improve metacognition skills and the results of development must meet the feasibility of aspects of readability, construction and content suitability. This is supported by the results of previous studies that have been carried out, namely research from Adriani \& Silitonga (2017), said that guided inquiry-based teaching modules in chemistry learning can increase the activeness and ability of students. Tiring et al. (2015), based on the results of his research, said that guided inquiry-based modules effectively improve learning outcomes of students' knowledge, attitudes and skills. Next, Ramdoniati et al. (2019), showed that PBL-based chemical teaching were quite effective with a score reaching 3.58 to improve metacognition skills in electrolyte and non-electrolyte solution subjects. Based on this background, with the implementation of inquiry-based chemical modules used by students, it is expected to improve metacognitive skills and chemistry learning outcomes of student.

\section{Methods}

\section{Population and samples}

The population in this study were all students of class XI Mulia Education Foundation Medan. While the sample is part or representative of the population to be studied. One class XI Science was selected as the sample determined by simple random sampling. 


\section{Development model}

The development model used is Development Research. The product developed was in the form of guided inquiry-based chemical modules on acidic base subjects. According to Gay (1990), development research is an attempt to develop an effective product to used in the school, and not to test theory.

The development model used is ADDIE which is a development model by showing the basic stages of development that are simple and easy to learn. The development model has five steps consisting of Analysis, Design, Development, Implementation, and Evaluation. This development model has focused on developing subjects matter.

\section{Instrument Research}

The instruments used in this development research are learning outcomes test questions, metacognitive questionnaires, and validation sheets. Data analysis in this study was conducted using descriptive analysis, including feasibility analysis, analysis of metacognitive questionnaire results, and analysis of learning outcomes test data.

The method of data collection in this study was a questionnaire technique to determine the feasibility of the module from lecturers and teachers as expert validators, questionnaire techniques to determine students' metacognitive skills, and test techniques for assessing knowledge learning outcomes. Testing the hypothesis using the t-test and assisted with SPSS 19.0.

\section{Results}

\section{Chemical book analysis}

The analysis of the three chemical books by researchers is based on syllabus in the 2013 curriculum. The results of the assessment of three chemistry books based on the content, language, presentation and graphic components as a whole can be seen in Table 1.

Based on the results of the analysis of three chemistry books, the average of each book, namely in book 1 , obtained an average value of 3.47 with fairly decent criteria, in book 2 the average score was 3.11 with sufficiently decent criteria, in book 3 obtain an average value of 3.03 with fairly decent criteria. So the three books need not be revised.

Table 1

Results of three books assessment by chemistry teachers

\begin{tabular}{llllll}
\hline \multirow{2}{*}{ Book } & \multicolumn{4}{c}{ Suitability Standard of Subjects Average } & \multirow{2}{*}{ Average } \\
\cline { 2 - 5 } & Content & Language & Presentation & Integrity & \\
\hline Book 1 & 3.27 & 3.47 & 3.35 & 3.55 & 3.47 \\
Book 2 & 3.01 & 3.14 & 2.866 & 3.43 & 3.11 \\
Book 3 & 3.01 & 3.21 & 2.741 & 3.14 & 3.03 \\
\hline
\end{tabular}

\section{Module development}

The module design is based on the syllabus 2013 and the results of book analysis. The next step is to develop a standard guided inquiry based module. After the development of the acid base module is completed, the next step is to standardize guided inquiry based modules. The overall results regarding the evaluator's responses to the Guided Inquiry-based module are presented in Table 2.

Based on the results of module standardization in Table 2, it can be concluded that guided inquiry based modules on acid-base matter that have been developed can be used as teaching matter in the chemistry learning process. 


\section{Data analysis of the test instrument}

Learning outcomes test instruments were tested first to determine the validity, reliability, level of difficulty, and differentiation of questions.

To measure the validity of each item, then the validity of expert judgment is carried out, so that there are 27 valid questions from 30 available questions. Reliability of the questions in this study used Kuder Richardson-20 (KR-20). The reliability of the test items obtained $r$ count $>$ rtable or $0.848>0.334$, it can be concluded that the overall item has a high level of reliability.

Analysis of the level of difficulty of the test is used to determine whether the test used is included in the category of tests that are easy, moderate or difficult. The results of the test of the difficulty level of the test indicate that of the 30 questions, there are 5 questions with easy categories and 25 questions in the medium category. Whereas for the differentiating power obtained from 30 questions, there are 25 questions categorized as fulfilling the requirements and 5 questions not fulfilling the requirements.

Table 2.

Module standardization results

\begin{tabular}{clll}
\hline No. & Eligibility Criteria & Average & Description of eligibility criteria \\
\cline { 2 - 4 } 1. & Content & 3.85 & The module is feasible and no need revision \\
2. & Language & 3.89 & The module is feasible and no need revision \\
3. & Presentation & 3.83 & The module is feasible and no need revision \\
4. & Integrity & 3.87 & The module is feasible and no need revision \\
\hline & Average & 3.86 & The module is feasible and no need revision \\
\hline
\end{tabular}

\section{Data analysis of the questionnaire instrument}

Questionnaire Metacognition skills taken from the Metacognitive Awareness Inventory (MAl) instrument are made by Schraw and Dennison that are tailored to the conditions of the students. Test the validity of the metacognition skills questionnaire using the Product Moment Correlation formula from Pearson with SPSS version 19.0. With the subject $(N)$ as many as 26 students on metacognition skills obtained $r_{\text {table }} 0.388$ at a significance level of $5 \%$. Price $r_{\text {count }}>r_{\text {table, }}$ it can be concluded that the item statement is valid.

Reliability on the scale of metacognition skills was calculated using the Cronbach Alpha formula with SPSS version 19.0. Then obtained alpha reliability coefficient value of 0.729 (good) so that the instrument is worthy of use.

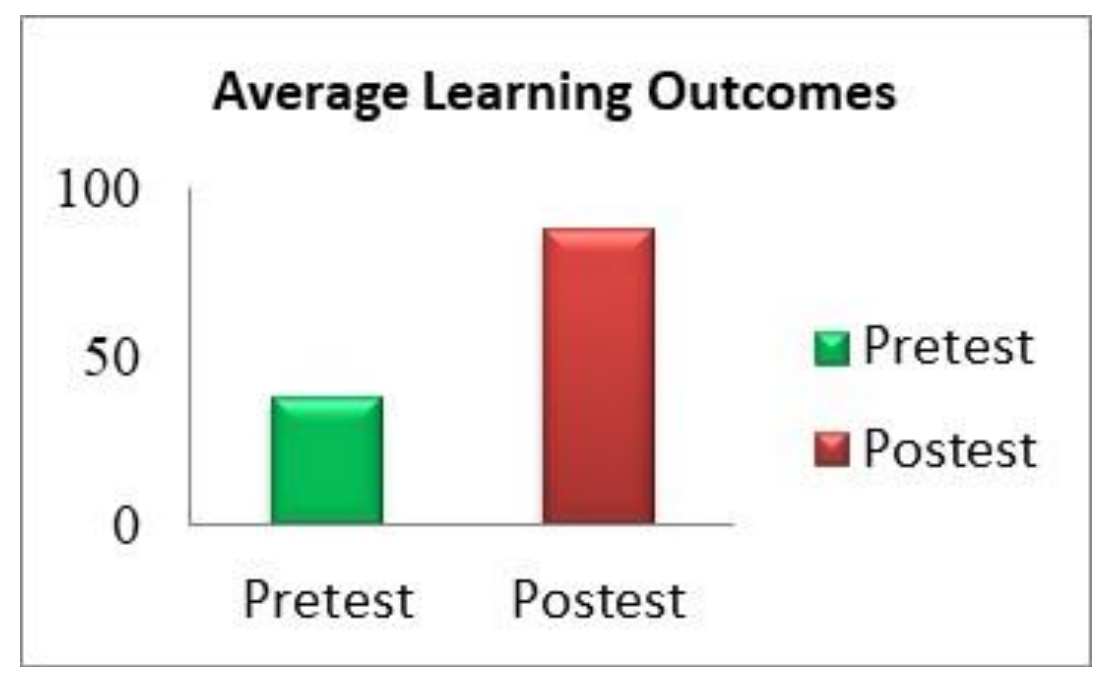

Fig 1. Average learning outcomes of students 


\section{Learning outcomes of student}

From the calculation data using Microsoft Excel it can be described the results of the average value of the pretest and the posttest value of the experimental class through the diagram in Fig 1.

In Fig 1 , the average pretest for the module trial is 38.08. After the pretest, sample was given a treatments and then posttest was carried out so that the average posttest of the experimental class was obtained at $\mathbf{8 7 . 6 9}$. So, there is an increase in learning outcomes of student by using guided inquiry-based module teaching on acid-base subjects.

Calculation of improvement in learning outcomes can be obtained from the average gain value of all students in the experimental class multiplied by $100 \%$. The experimental class gain averages are summarized in Table 3.

Based on Table 3, it can be seen that the\% gain of the experimental class is greater than 70 so that the criteria for improving learning outcomes of student using guided inquiry-based modules on acid-base subjects are high.

\section{Metacognitive skills of student}

The results of the students' metacognitive skills after using the module have a good average, with some students who have sufficient levels of metacognitive skills, and there are two students whose metacognitive level is very good.

\section{Hypothesis test}

The first hypothesis test is to find out whether the module developed is in accordance with the modified BSNP standard. This can be seen from the results of the validation questionnaire conducted by the validator expert.

The second hypothesis test is conducted to find out whether the alternative hypothesis $(\mathrm{Ha})$ is accepted or rejected. The hypothesis test that will be tested is the result of learning chemistry using a guided inquiry based module. Data from hypothesis test can be seen in Table 4 .

Table 3

Results of gain value

\begin{tabular}{lclll}
\hline Class & \multicolumn{1}{c}{ Criteria } & $\begin{array}{l}\text { Average of } \\
\text { Gain }\end{array}$ & \% Gain & Criteria \\
\hline Experiment & $\begin{array}{c}\% \mathrm{~g}<30=\text { low } \\
30<\mathrm{g}>70=\text { medium } \\
\% \mathrm{~g}>70=\text { High }\end{array}$ & 0.81 & $81 \%$ & High \\
& & & & \\
\hline
\end{tabular}

Table 4

Hypothesis test results of student learning outcomes

\begin{tabular}{cccc}
\hline Posttest Data of Experiment Class & $\mathbf{t}_{\text {count }}$ & $\mathbf{t}_{\text {table }}$ & Describe \\
\hline $\bar{X}$ & $=87.69$ & & \\
$\mathbf{s}=7.78$ & 8.321 & 1.708 & Ha accepted \\
$\mathbf{n}=26$ & & & \\
\hline
\end{tabular}

In Table 4, the value of $t_{\text {count }}$ is greater than $t_{\text {table }}(8.321>1.708)$, so Ho is rejected, which means $\mathrm{Ha}$ is accepted so it can be concluded that chemistry learning outcomes of student increase after being taught using guided inquiry based modules.

The third hypothesis test aims to determine the relationship between metacognition skills and chemistry learning outcomes of student. Then the existing data will be analyzed with SPSS 19. Table 5. below summarizes the analysis of the correlation hypothesis test. 
Table 5

Hypothesis test analysis

\begin{tabular}{ccl}
\hline $\mathbf{r}_{\text {count }}$ & \multicolumn{1}{c}{$\mathbf{r}_{\text {table }}$} & \multicolumn{1}{c}{ Describe } \\
\hline 0.472 & 0.388 & $\begin{array}{l}\text { Ho rejected } \\
\text { Ha accepted }\end{array}$ \\
\hline
\end{tabular}

Based on Table 5 , it is obtained that $r$ count $=0.472$ belongs to the category of moderate correlation. The results of the correlation obtained $r$ count $>$ rable is $0.472>0.388$, it can be concluded that $\mathrm{H}_{0}$ is rejected, and $\mathrm{Ha}$ accepted means "there is a relationship between metacognitive skills and chemistry learning outcomes of student ".

\section{Discussion}

This research is an experimental research in the field of education. This research was conducted at the Mulia Education Foundation Medan in May 2019 in the XI Science class in the 2018/2019 school year. This study aims to measure improvement in learning outcomes. Before conducting the research, the pretest is given by using 15 items that are valid and reliable. The pretest aims to determine the initial abilities of each student. After the learning is finished, then the posttest is done. This research method uses Development and Research (D\& R), which is to develop guided inquiry based modules on acid-base subjects. The hypothesis used in this study is that chemistry learning outcomes increase after being taught using guided inquiry-based modules. The hypothesis proposed is then tested statistically based on the data from the research that has been obtained. Based on the results of the research conducted, the average pretest was obtained at 38.08. Then the posttest is given. Based on the results of the test, the posttest score obtained in the experimental class was 87.69. This shows that in this study an increase in learning outcomes was $81 \%$. This means $\mathrm{Ha}$ is accepted, so that it can be said that chemistry learning outcomes of students' increase after being taught using guided inquiry based modules.

So, based on research conducted at the Mulia Education Foundation in Medan it can be concluded that learning using guided inquiry-based modules is effective for improving student learning outcomes. Guided inquiry-based chemistry modules that have been developed are appropriate for use in the learning process and are effective for improving student learning outcomes, in accordance with research conducted by Wardani (2015) which proves that guided inquiry modules are effective in improving students' understanding concepts and improving student character.

The relationship between metacognition skills and learning outcomes shows that the higher the metacognition skills of students', so the higher the student learning outcomes, and the lower the students' metacognitive skills, the lower the student learning outcomes. This is in line with Yunanti's research (2016), which states that if students' metacognitive skills are high, learning outcomes are also high. If associated with the learning process, metacognition is very important in learning because knowledge of cognitive processes can guide us in compiling and choosing strategies to improve cognitive performance. Metacognition awareness is a skill that causes a person to be trained to always design the best strategy in choosing, remembering, re-recognizing, managing the information they get, and in solving problems (Muhali, 2013).

If someone, especially the student, knows and realizes how he learns and the right strategy for him, or can someone say that he has good metacognition skills, then it can be ascertained that the learning process and understanding in learning will be better and the learning outcomes obtained will be better too. As according to lin which states that there is a close relationship between learning outcomes and metacognition skills. Efforts to improve one's cognitive skills need to be supported by an increase in metacognitive skills. In its application in learning activities or 
problem solving, cognitive and metacognitive processes can take place simultaneously, which support each other (Yustina, 2012; Purba et al. 2018).

The results of the last analysis of the processing of the hypothesis test data above show that $r_{\text {count }} \geq r_{\text {table }}(0.472 \geq 0.388)$, it can be concluded Ha is accepted at the $5 \%$ significance level. Thus, there is a relationship between metacognition skills and chemistry learning outcomes of student.

Furthermore, if interpreted into a correlation table, it was found that the relationship between metacognitive skills and chemistry learning outcomes of student was classified as a moderate correlation. This is in line with the research previously conducted by Muslihah Ahmad showing that there is a significant correlation between metacognition of students with learning achievement obtained $\left(r_{\text {count }}\right)$ of 0.405 which is included in the category of moderate correlation (Muslihah, 2014).

\section{Conclusion}

Based on the results of the study, it can be concluded that the module developed meets the criteria of the National Education Standards Agency (BSNP), with analysis of the data obtained: content eligibility $=3.85$; language eligibility $=3.89$; presentation eligibility $=3.83$; graphical feasibility $=$ 3.87 with valid criteria and no need revision; $t_{\text {count }}$ is greater than $t_{\text {table }}(8.321>1.708)$ then shows that chemistry learning outcomes of student increase after being taught using guided inquirybased modules; the results of the correlation obtained $r_{\text {count }}>r_{\text {table }}(0.472>0.388)$, it can be concluded that there is a relationship between metacognition skills and chemistry learning outcomes of students who are taught with guided inquiry-based modules. If a student knows and realizes how he is learning and the right strategy for him, or can someone say that he has good metacognition skills, then it can be ascertained that the learning process and understanding in learning will be better and the learning outcomes obtained will be better too.

\section{References}

Adriani, N., \& Silitonga, F. S. (2017). Pengembangan modul ajar kimia unsur berbasis inkuiri terbimbing fase development untuk mahasiswa pendidikan kimia. Jurnal Zarah, 5(2), 44-47, doi: 10.31629/zarah.v5i2.219

Bilgin, 1. (2009). The effects of guided-inquiry instruction incorporating a cooperative learning approach on university students' achievement of acid and bases concepts and attitude. Scientific Research and Essay, 4(10), 1038-1046.

Danial, M. (2010). Menumbuhkembangkan Kesadaran Dan Keterampilan Metakognisi Mahasiswa Jurusan Biologi Melalui Penerapan Strategi Pbl Dan Kooperatif Gi. Bioedukasi (Jurnal Pendidikan Biologi), 1(2), doi: 10.24127/bioedukasi.vli2.188

Dewi, C. A., \& Handayani, T. F. (2015). Validitas modul kimia berbasis problem based research (pbr) pada materi larutan elektrolit dan nonelektrolit. Prisma Sains: Jurnal Pengkajian Ilmu dan Pembelajaran Matematika dan IPA IKIP Mataram, 3(2), 54-58, doi: 10.33394/j-ps.v3i2.972.

Gay, L.R. (1990). Educational evaluation and measurement: Com-petecies for analysis and application second edition. Macmilan Publishing Compan, New York.

Marsita, R. A., Priatmoko, S., \& Kusuma, E. (2010). Analisis kesulitan belajar kimia siswa senior high school dalam memahami materi larutan penyangga dengan menggunakan two-tier multiple choice diagnostic instrument. Jurnal Inovasi Pendidikan Kimia, 4(1), 512-520.

Muhali. (2013). Analisis kemampuan metakognisi siswa dalam pembelajaran kimia. Jurnal Kependidikan Kimia "Hydrogen", 1(1), 1-7.

Muslihah, A., (2014). Korelasi keterampilan metakognitif mahasiswa dengan prestasi belajar struktur aljabar-1 jurusan tadris matematika fakultas tarbiyah IAIN Tulungagung tahun akademik 2013/2014. Skripsi. Tulungagung: IAIN Tulungagung. 
Novratilova, D., Kadaritna, N., \& Tania, L. (2015). Efektifitas problem solving dalam meningkatkan keterampilan mengelompokkan dan menyimpulkan pada asam basa. Jurnal Pendidikan dan Pembelajaran Kimia, 4 (1), 782-794.

Purba, D. N., Damanik, M., Silaban, S., \& Simatupang, L. (2018). The difference of student's activities and learning outcome with problem based learning using macromedia flash and handout. Jurnal Pendidikan Kimia, 10(3), 403-408, doi: 10.24114/jpkim.v10i3.12704

Pratiwi, 1., D, R. E., Silaban, R., \& Suyanti, R. D. (2019). Pengembangan modul berbasis inkuiri terbimbing pada materi hukum dasar kimia di sekolah menengah atas. Talenta Conference Series: Science and Technology (ST), 2(1), 187-193, doi: 10.32734/st.v2i1.340

Ramdoniati, N., Muntari, M., \& Hadisaputra, S. (2018). Pengembangan bahan ajar kimia berbasis problem based learning untuk meningkatkan keterampilan metakognisi. Jurnal Penelitian Pendidikan IPA, 5(1), 27-33, doi: 10.29303/jppipa.v5il.148

Ristiyani, E., \& Bahriah, E. S. (2016). Analisis kesulitan belajar kimia siswa di sman $\mathrm{x}$ kota tangerang selatan. Jurnal Penelitian dan Pembelajaran IPA, 2(1), 18, doi: 10.30870/jppi.v2i1.431

Santyasa, W. (2011). Metode penelitian pengembangan \& teori pengembangan modul. Makalah Disajikan dalam Pelatihan Bagi Para Guru TK, SD, SMP, Senior High School, dan SMK, pp. 5060.

Tiring, S. S. N. N., Saputro, S., \& Utomo, S. B. (2015). Pengembangan modul kimia berbasis inkuiriterbimbing pada materi identifikasi gugus fungsi kelas $\mathrm{x}$ smk kimia industri. Jurnal Inkuiri, 4(3), 51-59.

Wardani, S., Nurhayati, S., \& Safitri, A. (2015). The effectiveness of the guided inquiry learning module towards students. (2016). International Journal of Science and Research (IJSR), 5(6), 1589-1594, doi: 10.21275/v5i6.nov164512

Weerawardhana, A., Ferry, B., \& Brown, C. A. (2006). Use of visualisation software to support understanding of chemical equilibrium: The importance of appropriate teaching strategies. Proceedings of The 23rd Annual Ascilite Conference, The University of Sydney, pp. 1-10.

Yunanti, E. (2016). Hubungan antara kemampuan metakognitif dan motivasi belajar dengan hasil belajar biologi kelas ix Mts N Metro tahun pelajaran 2013/2014. Bioedukasi (Jurnal Pendidikan Biologi), 7(2), doi: 10.24127/bioedukasi.v7i2.609

Yustina, 1.l., \& Sugiarto, B. (2012). Korelasi antara keterampilan metakognitif dengan hasil belajar siswa di senior high schooln 1 Dawarblandong, Mojokerto. Unesa Journal of Chemical Education, $1(2), 78-83$. 